\title{
Absorption, Translocation, and Metabolism of Chlorsulfuron in Kentucky Bluegrass and Tall Fescue
}

\author{
J.M. Goatley. Jr. ${ }^{1}$, A.J. Powell. Jr. ${ }^{2}$, M. Barrett ${ }^{3}$, and W.W. Witt ${ }^{4}$ \\ Agronomy Department, University of Kentucky, Lexington, KY 40546 \\ Additional index words. Poa pratensis, Festuca arundinacea, selective control
}

\begin{abstract}
Laboratory studies were conducted to determine the basis for chlorsulfuron selectivity between Kentucky bluegrass (Poa pratensis L. Cv. Kenblue) and tall fescue (Festuca arundinacea Schreb. Cv. Rebel). Tall fescue absorbed and translocated more foliar-applied $\left[{ }^{14} \mathrm{C}\right]$-labeled chlorsulfuron from the treated leaf than Kentucky bluegrass. The two species absorbed similar amounts of chlorsulfuron from nutrient solution into the roots, but tall fescue translocated more of the absorbed radioactivity to the shoots. Tall fescue metabolized chlorsulfuron in the shoots slightly more slowly than Kentucky bluegrass. Allof these factors apparently contributed to the higher tolerance of Kentucky bluegrass than of tall fescue to chlorsulfuron. Chemical name used: (2-chloro-N-[[ 4-methoxy-6-methyl-1,3,5 -triazin2-yl)amino]-carbonyl] benzenesulfonamide) (chlorsulfuron).
\end{abstract}

Previous studies have shown the potential for using chlorsulfuron for selective control of tall fescue in Kentucky bluegrass turf (LaRocque and Christians, 1985; Maloy and Christians, 1986; Goatley et al., 1990). Accordingly, both grasses showed some degree of tolerance to chlorsulfuron, but Kentucky bluegrass tolerance was exceptional at high chlorsulfuron levels.

The degree of chlorsulfuron tolerance and the rate at which it is metabolized have been strongly correlated in previous studies and the rate of its metabolic conversion has been proposed to be the primary selectivity mechanism between tolerant and sensitive plants (Sweetser et al., 1982; Hageman and Behrens 1984; Hutchison et al., 1984). In tolerant plants, the proposed metabolic pathway of chlorsulfuron is hydroxylation followed by glycoside conjugation (Sweetser et al., 1984). The metabolic processes for chlorsulfuron degradation between tolerant grasses and broadleaves differ in that initial hydroxylation of chlorsulfuron occurred on the phenyl ring in tolerant grasses and on the heterocyclic ring in tolerant broadleaves (Sweetser et al., 1982; Hutchison et al., 1984). Differential metabolism based on the site of uptake has also been reported (Peterson and Swisher, 1985). The objective of this study was to determine the basis for chlorsulfuron selectivity between Kentucky bluegrass and tall fescue. The possible selectivity mechanisms studied were: a) foliar absorption and translocation, b) root absorption and translocation, and c) metabolism following foliar treatments.

\section{Materials and Methods}

Foliar absorption and translocation. Thirty 10.2-cm-diameter plugs each of Kentucky bluegrass ('Kenblue') and tall fescue ('Rebel') were collected with a golf green cup cutter and placed in a greenhouse. The plugs were 4 to $6 \mathrm{~cm}$ thick and were placed in 1-liter plastic containers filled with a Maury silt loam (Typic Paleudalf) soil, $\mathrm{pH}$ 6.5. The plugs were watered daily and fertilized as needed with a nutrient solution (Maynard and Barker,

Received for publication 19 Oct. 1989. Funding provided by Kentucky Agriculture Experiment Station. The cost of publishing this paper was defrayed in part by the payment of page charges. Under postal regulations, this paper therefore must be hereby marked advertisement solely to indicate this fact.

'Prescntly Assistant Professor, Agronomy Dept., Mississippi State Univ., Mississippi State, MS 39762

${ }^{2}$ Extentsion Professor.

${ }^{3}$ Associate Professor.

${ }^{4}$ Associate Professor.
1970). Clipping height was maintained at $\approx 15 \mathrm{~cm}$. Plugs were grown for 1 month to allow them to acclimate to greenhouse conditions.

Individual transplants were separated from the plugs after 1 month and roots were washed and trimmed to $10 \mathrm{~cm}$. Kentucky bluegrass rhizomes were trimmed to $1 \mathrm{~cm}$. Transplants were planted in 500-ml polystyrene cups filled with a 2 Maury soil : 1 vermiculite $(\mathrm{v} / \mathrm{v})$ mix. The transplants were grown in a greenhouse for at least 8 weeks before testing. Plants were subirrigated to maintain soil moisture near field capacity. Fertilization and clipping height were as described previously. Fifteen transplants each of Kentucky bluegrass and tall fescue were selected randomly for use in the foliar absorption and translocation studies. The transplants were clipped to a $15-\mathrm{cm}$ height 3 days before treatment.

Uniformly ring-labeled $\left[{ }^{14} \mathrm{C}\right]$ chlorsulfuron [specific activity of $11.5 \mathrm{Ci} \cdot \mathrm{mg}-\mathrm{l}(\mathrm{l} \mathrm{Ci}=37 \mathrm{GBq})]$ at $0.44 \mathrm{~g} \cdot$ liter $^{-1}$, acetone $(10 \% \mathrm{v} / \mathrm{v})$, and $0.2 \%(\mathrm{v} / \mathrm{v})$ oxysorbic (polyoxyethylene sorbitanmonolaurate, $20 \mathrm{POE}$ ) in deionized water were prepared for foliar treatments. This solution $(10 \mu 1)$ was applied with a syringe delivering $0.5-\mu 1$ droplets to the adaxial surface of the youngest fully expanded leaf of both Kentucky bluegrass and tall fescue. Total leaf area covered on both species was $2 \mathrm{~cm}^{2}$. This treatment simulated field treatments where 486 liter of spray solution/ha containing $0.4 \mathrm{~g}$ chlorsulfuron/liter was used to apply chlorsulfuron at $\approx 0.2 \mathrm{~kg}$ a.i./ha (Goatley et al., 1990). This level provided significant control of tall fescue and was tolerated by Kentucky bluegrass.

The plants were placed in the greenhouse with $16 \mathrm{hr}$ of supplemental lighting supplied by metal halide lamps (250 $\mu \mathrm{mol} \cdot \mathrm{s}^{-1} \cdot \mathrm{m}^{-2} \mathrm{PPF}$ ) following treatment. Foliar absorption and translocation of $\left[{ }^{14} \mathrm{C}\right]$ chlorsulfuron was determined $3,6,24,48$, and $96 \mathrm{hr}$ after treatment with three replications per harvest. At harvest, the treated leaf was removed from each plant and washed in $20 \mathrm{ml}$ of acetone for $30 \mathrm{sec}$ and an aliquot was then removed to determine $\left[{ }^{14} \mathrm{C}\right]$ activity by liquid scintillation spectrophotometry. All data were corrected for background and quenching.

The remaining plant parts were separated into treated shoots (including crown), other foliage (daughter plants arising from tillers and rhizomes), and rhizomes (Kentucky bluegrass only), and each section was lyophilized. Samples were oxidized in a Packard Model B306 Tri-Carb sample oxidizer (Packard Instrument Co., Downers Grove, 111). Released $\left[{ }^{14} \mathrm{CO}_{2}\right]$ was quantitated by liquid scintillation spectrophotometry. 
The total percentage recovery of $\left[{ }^{14} \mathrm{C}\right]$ chlorsulfuron applied was calculated by combining the $\left[{ }^{14} \mathrm{C}\right]$ activity recovered in the washes and plant parts, and dividing by total $\left[{ }^{14} \mathrm{C}\right]$ activity applied. The percentage of $\left[{ }^{14} \mathrm{C}\right]$ chlorsulfuron absorbed was determined by dividing the total activity found in all plant parts by the amount of $\left[{ }^{14} \mathrm{C}\right]$ applied. Percentage translocation was determined by dividing total activity from plant parts by the total $\left[{ }^{14} \mathrm{C}\right]$ chlorsulfuron activity absorbed.

Root absorption and translocation. Kentucky bluegrass and tall fescue transplants were prepared as described previously. Eight weeks after transplanting, individual plants were selected and roots were washed and trimmed. Eight plants each of Kentucky bluegrass and tall fescue were placed in 125-ml flasks containing, an aerated nutrient solution (Maynard and Barker, 1970). The volume of the solution was adjusted daily to ensure that the roots remained in solution. The transplants were supported by split foam plugs and flasks were placed in a growth chamber with supplemental lighting $\left(200 \mu \mathrm{mol} \cdot \mathrm{s}^{-1} \cdot \mathrm{m}^{-2} \mathrm{PPF}\right)$. Daylength was $16 \mathrm{hr}$ with a $25 / 15 \mathrm{C}$ day/night cycle. The plants were allowed to grow for 2 weeks before treatment.

Three plants of each species were transferred to 50-ml test tubes containing $40 \mathrm{ml}$ of nutrient solution. Two microliters of $\left[{ }^{14} \mathrm{C}\right]$ chlorsulfuron solution $\left(4: 4 \mathrm{~g} \cdot \mathrm{liter}^{-1}\right)$ prepared in acetone were added directly to the nutrient solution. The $2 \mu \mathrm{l}$ contained $0.11 \mu \mathrm{Ci}$, and gave a final chlorsulfuron concentration in the solution of $0.7 \mu \mathrm{M}$. The volume of nutrient solution was returned to $40 \mathrm{ml}$ daily. Three replicates for each species were harvested after $96 \mathrm{hr}$.

Roots were washed at the end of the treatment period in 20 $\mathrm{ml}$ of distilled water for $30 \mathrm{sec}$ to remove any chlorsulfuron not absorbed. Aliquots of the wash solution and the nutrient solution were taken, and $\left[{ }^{14} \mathrm{C}\right]$ activity was determined by liquid scintillation spectrophotometry. Plants were then sectioned and radioactivity associated with the plant parts was determined as described previously.

Foliar metabolism. Kentucky bluegrass and tall fescue plants were prepared as described previously. Two leaves (on each of three plants per species) were treated with a total of $0.11 \mu \mathrm{Ci}$ per plant. Following treatment, the plants were placed in a growth chamber under the conditions described previously.

Four days after treatment, the shoots (including the crown) of the treated plants were harvested by clipping just below soil level. The two treated leaves of each plant were removed and washed in $20 \mathrm{ml}$ of acetone for $30 \mathrm{sec}$ to remove $\left[{ }^{14} \mathrm{C}\right]$ remaining on the leaf surface. An aliquot of the wash was used for radioactivity determination as described previously. The treated leaves and remaining shoot material were combined and chlorsulfuron and metabolizes were extracted by a method similar to that reported by Sweetser et al. (1982). Radioactive components of the plant extracts were separated using high performance liquid chromatography (HPLC). A Varian 5040 HPLC (Varian Instruments, Mountain View, Calif.) equipped with a Varian Micropak MCH-10 column $(4.0 \times 300 \mathrm{~mm})$ was used for the analysis. The chromatographic conditions consisted of a mobile phase of acetonitrile plus water: $\mathrm{H}_{2} \mathrm{PO}_{4}\left[0.1 \% \mathrm{H}_{2} \mathrm{PO}_{4}(\mathrm{v} / \mathrm{v})\right]$ in a linear gradient from $5 \%$ to $100 \%(\mathrm{v} / \mathrm{v})$ acetonitrile for $30 \mathrm{~min}$ and at a flow rate of $1 \mathrm{ml} \cdot \mathrm{min}^{-1}$. The mobile phase was then returned to $5 \%$ acetonitrile in a linear gradient over the next $60 \mathrm{~min}$. Fractions eluting from the column were collected at l-rein intervals and radioactivity was determined as described previously. Standards for parent chlorsulfuron were prepared by extracting untreated plant tissue and adding $\left[{ }^{14} \mathrm{C}\right]$ chlorsulfuron to the extracts before HPLC injection. Under these conditions, $97 \%$ of the $\left[{ }^{14} \mathrm{C}\right]$ chlorsulfuron eluted after 21 to $24 \mathrm{~min}$.

All reported experiments were repeated and the data presented are the pooled results of all replicates, because statistical analyses indicated no significant differences between experiments. A completely randomized design was used for each experiment. Data were subjected to analyses of variance, regression analyses, and means were separated by $t$ tests.

\section{Results and Discussion}

Foliar absorption and translocation. An average of $82 \%$ of the $\left[{ }^{14} \mathrm{C}\right]$ applied as chlorsulfuron was recovered. Absorption of chlorsulfuron continued over the 96-hr treatment period for both Kentucky bluegrass and tall fescue (Table 1). There was little difference between the two species at any one sampling; however, tall fescue absorbed slightly more chlorsulfuron than Kentucky bluegrass when averaged across sampling times. The amount of chlorsulfuron absorption for the two grasses, $\quad \approx 30 \%$, was lower than values reported for several species (Sweetser et al., 1982), but similar to absorption observed with Canada thistle (Cirsium arvense Stop.) and tartary buckwheat (Fagopyrwm tartaricum Gaertn.) (Hageman and Behrens, 1984; Bestman and VandenBorn, 1983). Differences in plant species and growing conditions may have contributed to the differences in the level of chlorsulfuron absorption between experiments of Sweetser et al. (1982) and experiments reported here.

The translocation of radioactivity from $\left[{ }^{14} \mathrm{C}\right]$ chlorsulfurontreated leaves to untreated plant parts was low in tall fescue and Kentucky bluegrass (Table 2). The data presented are averaged across sampling times because there were no significant differences in the percentages of absorbed radioactivity translocated

Table 1. $\left[{ }^{14} \mathrm{C}\right]$ Chlorsulfuron absorption following foliar treatments to Kentucky bluegrass and tall fescue.

\begin{tabular}{|c|c|c|c|}
\hline $\begin{array}{c}\text { Hours after } \\
\text { treatment }\end{array}$ & $\begin{array}{l}\text { Kentucky } \\
\text { bluegrass }\end{array}$ & & $\begin{array}{c}\text { Tall } \\
\text { fescue }\end{array}$ \\
\hline \multicolumn{4}{|c|}{ Percent of absorbed radioactivity } \\
\hline 3 & 2.5 & & 4.4 \\
\hline 6 & 4.7 & & 6.2 \\
\hline 24 & 13.9 & & 16.1 \\
\hline 48 & 14.6 & * & 24.4 \\
\hline 96 & 27.0 & & 31.3 \\
\hline Grand mean ${ }^{z}$ & 12.5 & * & 16.5 \\
\hline Trend analyses ${ }^{y}$ & $\mathrm{~L}^{* *}$ & & $\mathrm{~L}^{* *}, \mathrm{Q}^{* *}$ \\
\hline
\end{tabular}

${ }^{7}$ Mean percent absorption averaged across all time periods.

${ }^{y}$ Linear $(\mathrm{L})$ or quadratic $(\mathrm{Q})$ trends according to regression analyses.

Statistical significance at $P=0.05$ and 0.01 , respectively. Means within the same row were compared by t tests. Data are the means of six observations.

Table 2. Distribution of foliar-absorbed $\left[{ }^{14} \mathrm{C}\right]$ chlorsulfuron radioactivity in Kentucky bluegrass and tall fescue $96 \mathrm{hr}$ after treatment.

\begin{tabular}{llllll}
\hline \hline & \multicolumn{5}{c}{ Plant part } \\
\cline { 2 - 6 } \multicolumn{1}{c}{ Species } & $\begin{array}{c}\text { Treated } \\
\text { leaf }\end{array}$ & $\begin{array}{c}\text { Other } \\
\text { foliage }\end{array}$ & Shoot & Root & Rhizome \\
\hline \multirow{5}{*}{ Kentucky bluegrass } & $90.6 \mathrm{a}^{*}$ & $4.5 \mathrm{~b}$ & $2.2 \mathrm{~b}$ & $2.1 \mathrm{a}$ & 0.6 \\
Tall fescue & $86.2 \mathrm{~b}$ & $7.0 \mathrm{a}$ & $4.8 \mathrm{a}$ & $2.0 \mathrm{a}$ & -- \\
\hline
\end{tabular}

${ }^{2}$ Radioactivity distribution is averaged across sampling times.

*Mean separation within a column by $t$ tests, $P=0.05$. Data are the means of six observations. 
Table 3. Absorption and distribution of radioactivity in Kentucky bluegrass and tall fescue after $96 \mathrm{hr}$ of root exposure to [ $\left.{ }^{14} \mathrm{C}\right] \mathrm{chlorsulfuron}$.

\begin{tabular}{|c|c|c|c|c|}
\hline \multirow[b]{2}{*}{ Species } & \multirow[b]{2}{*}{ Absolution } & \multicolumn{3}{|c|}{ Distribution } \\
\hline & & Root & Shoot & Rhizome \\
\hline & Percent of applied & & bsorbed & \\
\hline Kentucky bluegrass & $10.3 \mathrm{a}^{*}$ & $45.8 \mathrm{a}$ & $50.6 \mathrm{~b}$ & 3.6 \\
\hline Tall fescue & $9.0 \mathrm{a}$ & $19.2 \mathrm{~b}$ & $80.8 \mathrm{a}$ & $\cdots$ \\
\hline
\end{tabular}

* Mean separation within a column by t tests, $P=0.05$. Data are the means of six observations.

Table 4.. Percent radioactivity recovered as $\left[{ }^{14} \mathrm{C}\right]$ chlorsulfuron and an unidentified $\left[{ }^{14} \mathrm{C}\right]$ chlorsulfuron metabolite in Kentucky bluegrass and tall fescue.

\begin{tabular}{|c|c|c|}
\hline Species & {$\left[{ }^{14} \mathrm{C}\right]$ ChIorsulfuron } & $\begin{array}{c}{\left[{ }^{14} \mathrm{C}\right] \text { Chlorsulfuron }} \\
\text { metabolize }\end{array}$ \\
\hline & \multicolumn{2}{|c|}{ Per-cent of recovered radioactivity' } \\
\hline Kentucky bluegrass & $5.8 \mathrm{~b}^{*}$ & $42.5 \mathrm{a}$ \\
\hline Tall fescue & $15.3 \mathrm{a}$ & $41.0 \mathrm{a}$ \\
\hline
\end{tabular}

'Plants extracted $96 \mathrm{hr}$ after exposure to $\left[{ }^{14} \mathrm{C}\right]$ chlorsulfuron.

*Mean separation within a column by t tests, $P=0.05$. Data are the means of six observations.

between sampling times for either species. The amount translocated $(10 \%$ to $15 \%)$ is similar to previous reports of chlorsulfuron translocation (Sweetser et al., 1982). Tall fescue translocated slightly more chlorsulfuron than Kentucky bluegrass. This difference resulted in higher amounts of radioactivity in the other foliage and shoot material of tall fescue than of Kentucky bluegrass. There was no difference in levels of chlorsulfuron found in the roots of the two species, and $<1 \%$ of the absorbed radioactivity was detected in the Kentucky bluegrass rhizomes (Table 2). The limited translocation of chlorsulfuron from treated leaves and the minor translocation to the roots are consistent with published reports on chlorsulfuron movement in plants (Sweetser et al., 1982). Movement of chlorsulfuron following foliar treatment appears to be primarily restricted to the treated shoot material. In prior studies, differences in absorption and translocation did not explain chlorsulfuron selectivity between tolerant and susceptible species (Sweetser et al., 1982).

Root absorption and translocation. The average recovery of radioactivity from root-applied $\left[{ }^{14} \mathrm{C}\right]$ chlorsulfuron was $83 \%$. Kentucky bluegrass and tall fescue absorbed similar amounts of chlorsulfuron over $96 \mathrm{hr}$ of root exposure to the herbicide (Table $3)$. The absorption value $(\approx 10 \%)$ is similar to reported root uptake levels for chlorsulfuron-susceptible Canada thistle (Peterson and Swisher, 1985). These data also indicated much reduced absorption of chlorsulfuron from root as compared to foliar treatments (Table 1).

While there was little difference in root absorption of chlorsulfuron between the two grass species, there was a major difference in the distribution of the absorbed radioactivity. Movement of radioactivity from the roots to the shoots was favored in tall fescue, with $19 \%$ being retained in the roots as compared to $46 \%$ in Kentucky bluegrass (Table 3 ). Slightly <4\% of the absorbed radioactivity was found in the Kentucky bluegrass rhizomes. The large difference in $\left[{ }^{14} \mathrm{C}\right]$ translocation to the shoots between Kentucky bluegrass and tall fescue could be an important factor in chlorsulfuron selectivity between the two species. The magnitude of difference in root translocation to shoots between the species was much greater than the translocation differences observed following foliar treatment (Table 2). The large amounts of radioactivity remaining in the bluegrass roots suggested the possibility of sequestering of the chlorsulfuron, per- haps by metabolic alteration of the chlorsulfuron molecule at a more rapid rate than in tall fescue. The primary metabolic pathway for chlorsulfuron in tolerant grasses was proposed to proceed from hydroxylation of the phenyl ring to conjugation with glucose (Sweetser et al., 1982). Glycosides formed by conjugation with an introduced chemical were reported to remain within the plant tissues in which they were formed (Miller, 1940; Bull and Stokes, 1970).

Chlorsulfuron metabolism. Both Kentucky bluegrass and tall fescue metabolized the majority of the foliar-absorbed $\left[{ }^{14} \mathrm{C}\right]$ chlorsulfuron $96 \mathrm{hr}$ after treatment (Table 4). However, tall fescue apparently contained a higher level of unmetabolized chlorsulfuron than Kentucky bluegrass. A single (and apparently the same) metabolize was found in the extracts from the two grass species. The elution time for the metabolize was 14 to 16 min after injection into the chromatography for both species. Whereas the Kentucky bluegrass and tall fescue differed in the amount of unmetabolized chlorsulfuron present, both had $\approx 40 \%$ of the extracted radioactivity as the metabolize. Although this metabolize was not identified due to the lack of an available standard, the retention time before elution was similar to that reported for the 5-glycoside of chlorsulfuron (Sweetser et al., 1982). This is the primary metabolize in some tolerant grass species.

The differences in the rate of chlorsulfuron metabolism were not as pronounced between the tolerant plant (Kentucky bluegrass) and the susceptible plant (tall fescue), as had been reported in previous studies (Sweetser et al., 1982; Hageman and Behrens, 1984; Hutchison et al., 1984). Differences in chlorsulfuron metabolism in previous studies were large enough that differential metabolism was proposed as the basis for selectivity. However, Kentucky bluegrass and tall fescue apparently are much more similar in their degree of tolerance to chlorosulfuron applications than other species. This could explain the lack of complete tall fescue control observed previously in field studies and the need for higher levels of chlorsulfuron in spring applications (Maloy and Christians, 1986; Goatley et al., 1990).

The slight, but significant, differences in foliar absorption, translocation, and metabolism apparently contributed to greater tolerance of Kentucky bluegrass to chlorsulfuron. Although metabolism of chlorsulfuron in the roots was not determined, the large differences in translocation of root-absorbed chlorsulfuron between the two species suggests the possibility of compartmentalization of the chlorsulfuron by the Kentucky bluegrass. Differential rates of chlorsulfuron metabolism in Canada thistle roots, compared to shoots, has been proposed as a selectivity mechanism (Peterson and Swisher, 1985). Future studies are needed to determine if root sequestering and metabolism of chlorsulfuron is the primary basis of Kentucky bluegrass tolerance. Additional research is also needed to determine any longterm differences in chlorsulfuron absorption, translocation, and metabolism between tall fescue and Kentucky bluegrass. Because visible symptoms of chlorsulfuron's herbicidal activity 
can require weeks to appear, studies of a duration exceeding 96 $\mathrm{hr}$ might be warranted.

\section{Literature Cited}

Bestman, H.D. and W.H. VandenBorn. 1983. Chlorsulfuron: Effect on and behavior in tartary buckwheat (Fagopynun tartaricum (L.) Gaertn.). Weed Sci. Sot. Amer. p. 203. (Abstr.)

Bull, D.L. and R.A. Stokes. 1970. Metabolism of dimethyl p-(methylthio) phenyl phosphate in animals and plants. J. Agr. Food Chem. 18:1134-1138.

Goatley, J.M., Jr., A.J. Powell, Jr., W.W. Witt, and M. Barrett. 1990. Control of tall fescue in Kentucky bluegrass turf with selective herbicides. HortScience 25:449-451:

Hageman, L.H. and R. Behrens. 1984. Basis for response differences of two broadleaf weeds to chlorsulfuron. Weed Sci. 32: 162-167.

Hutchison, J, M., R. Shapiro, and P.B. Sweetser. 1984. Metabolism of chlorsulfuron by tolerant broadleaves. Pest. Biochem. Phys. 22:243247.
LaRocque, D.J. and N.E. Christians. 1985. Selective control of tall fescue in Kentucky bluegrass with chlorsulfuron. Agron. J. 77:8689.

Maloy, B.M. and N.E. Christians. 1986. Tolerance of tall fescue and Kentucky bluegrass to chlorsulfuron under field conditions. Weed Sci. 34:431-434.

Maynard, D.N. and A.V. Barker. 1970. Nutriculture: A guide to the soilless culture of plants. Univ. of Mass., Amherst, Coop. Ext. Serv. Publ. 41:10-11.

Miller, L.P. 1940. Formation of B-O -chlorophenyl-gentibioside in gladiolus corms from absorbed O-chlorophenol. Contrib. Boyce Thompson Res. Inst. $11: 271-279$.

Peterson, P.J. and B.A. Swisher. 1985. Absorption, translocation, and metabolism of ${ }^{14} \mathrm{C}$-chlorsulfuron in Canada thistle (Cirsium arvense). Weed Sci. 33:7-11.

Sweetser, P. B., G.S. Schow, and J.M. Hutchinson. 1982. Metabolism of chlorsulfuron by plants: Biological basis for selectivity of a new herbicide for cereals. Pest. Biochem. Phys. 17:8-23. 